\title{
急激な過渡を伴う気液二相流の数值解析 \\ Numerical Analysis of Gas-Liquid Two-Phase Flow with Rapid Transition
}

\author{
$\bigcirc$ 学 行正章典(阪大院) 学 仲角 稔(阪大院) 正 松本忠義(阪大) \\ 正 大川富雄(阪大) 正 片岡 勲(阪大) \\ Akinori YUKIMASA Minoru NAKAZUMI Tadayoshi MATSUMOTO Tomio OKAWA Isao KATAOKA \\ Department of Mechanophysics Engineering, Osaka University
}

\begin{abstract}
Accurate prediction of gas-liquid two-phase flow with rapid transition is of significant importance to design various industrial plants and to evaluate their safety. However, the one-dimensional two-fluid model that is often used for these purposes requires constitutive equations and most of them are based on the experimental data of two-phase flow in steady state. Thus, to confirm the applicability of the one-dimensional two-fluid model to the transient state, several two-phase parameters during rapid transition were measured and they were compared with the numerical solution of the one-dimensional two-fluid model. As a result, the agreement between the numerical solutions and the experimental data was not deteriorated during the transition. This would imply that the one-dimensional two-fluid model is applicable to the transient twophase flow within the present experimental conditions.
\end{abstract}

Key Words: Gas-Liquid Two-Phase Flow, Rapid Transition, One-Dimensional Two-Fluid Model

\section{1. 緒言}

急激な過渡時における気液二相流の挙動を正確に予測す ることは、様々なエネルギ一機器を安全かつ合理的に設計 する上できわめて重要である。しかし，一次元二流体モデ ル等で使用される構成式の多くは定常状態で取得されたデ 一夕を基に開発されているため, 特に事故時等に発生し得 る急激な過渡変化を伴う気液二相流に対する適用性は十分 に明らかではない，本研究では、過渡時におらる気液二相 流の流動パラメータの変化を体系的に調ベ、各種構成式の 過渡状態に対する適用性を検討するための実験データベー スを取得する.さらに、一次元二流体モデルに基づく数値 解析を実施するとともに数值解と実験データの比較を行い、 定常状態において取得された実験データに基づく構成式の 過渡状態に対する適用性を検討する。

\section{2. 実験装置と実験条件}

実験装置の概略を図 1 に示寸。実験に用いる供試管は内 径 $19.7 \mathrm{~mm}$ の透明アクリル製円管で，鉛直に設置される. 液相および気相には、各ヶ常温・常圧の水および空気を用 いる。水はポンプにより循環し，空気はコンプレッサーよ り供給する。気液は円管下部のミキサーで混合された後、 円管内を上昇する．ミキサー部には直径 $3 \mathrm{~mm}$ の 2 本のアル ミ管が水平かつ互いに垂直に設置されており，各アルミ管 の側面にあけられた約 30 個の小孔（直径 $0.25 \mathrm{~mm}$ ）より空 気が注入される。気液は測定部を通過した後に試験部上部 で気水分離され，空気は大気中に開放される。

実験は、まず円管下部から水と空気を一定量注入して定 常状態とする. その後, 液体の質量流量 $W_{L}$ を一定に保った 状態で気相質量流量 $W_{G}$ をステップ状に変化させて鉛直円管 部に過渡状態を実現し，再び定常状態となった後に測定を 終了する．気液の流量は、液流量は超音波流量計により、 気相流量は熱式質量流量計により計測する。また，気液混 合部（ミキサ）におけるゲージ压力 $P$ ，およびその上方 $1051 \mathrm{~mm}-2354 \mathrm{~mm}$ の区間における差圧 $\Delta P$ を各々圧力変換 器, 差圧変換器を用いて計測する.

\section{3. 界面せん断力の評価}

過渡気液二相流の解析に先立って，定常状態では正確な 予測を与える構成式を準備する必要がある。このため, $J_{G}=$ 0.4-5.0 m/s, $J_{L}=0.08-5.0 \mathrm{~m} / \mathrm{s}$ の範囲で定常実験を実施した.

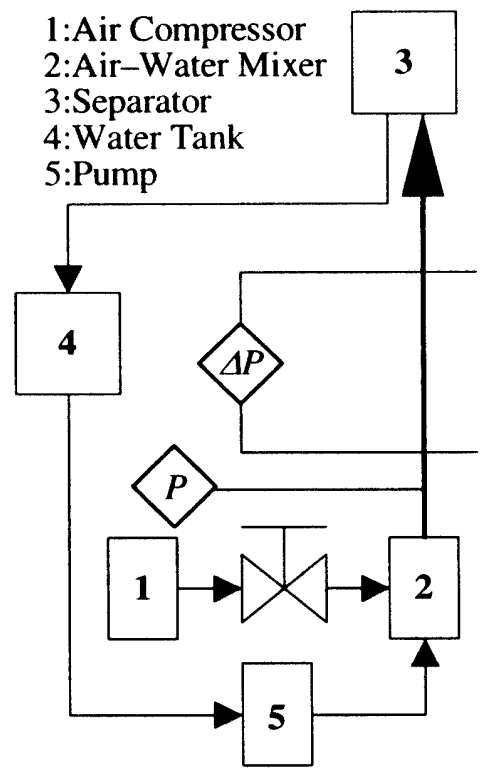

Fig. 1 Schematic diagram of experimental facility

まず，加速損失の影響は無視できるものとすると，試験部 の圧力損失 $\nabla P$ は次式で計算される.

$$
\nabla P=M_{w}+\left(\alpha_{G} \rho_{G}+\alpha_{L} \rho_{L}\right) g
$$

ここで、 $M_{w}$ は摩擦損失、 $\alpha$ は体積率、 $\rho$ は密度， $g$ は重力加 速度, 添字の $G$ と $L$ は各々気相と液相を表す。定常実験で 計測された $\nabla P$ を用いるとともに， $M_{w}$ は Lockhart-Martinelli の方法により評価できるものとすると，式(1)より試験部に おけるボイド率 $\alpha_{G}$ を推算できる。一方、二流体モデルにお ける界面せん断力 $M_{i}$ は、ドリフトフラックスモデルにおけ るドリフト速度 $V_{G I}$ および分布定数 $C_{0}$ を用いて以下のよう に表すことができる(1).

$$
\begin{aligned}
& M_{i}=C_{i}\left|C_{1} V_{G}-C_{0} V_{L}\right|\left(C_{1} V_{G}-C_{0} V_{L}\right) \\
& \text { ここで } \\
& C_{i}=\alpha_{G} \alpha_{L}^{3}\left(\rho_{L}-\rho_{G}\right) g / V_{G J}^{2}
\end{aligned}
$$




$$
C_{1}=\left(1-\alpha_{G} C_{0}\right) / \alpha_{L}
$$

である。式(2)-(3)より、 $V_{G /}$ および $C_{0}$ の相関式を与えれば、 $M_{i}$ が評価可能となることがわかる. 式(1)より算出される $\alpha_{G}$ を用いて全体積流束 $J_{T}=J_{G}+J_{L}$ と気相平均速度 $J_{G} / \alpha_{G}$ の関 係を調べた結果を図 2 に示す。図中の線は、以下に示寸 Nicklin 式 $^{(2)}$

$$
V_{G J}=0.35 \sqrt{g D}
$$

によりドリフト速度を評価し、 $C_{0}$ を $1.1,1.2,1.3$ とした場合 の予測值である。本実験では気泡流からチャーン流に至る

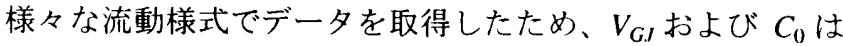
一定值とはならない.しかしながら、各実験条件で計算さ れる $C_{0}$ は、 $J_{L}$ がきわめて小さい場合を除いて $J_{T}$ の関数とし て概ね次式により相関できる（図 3 参照）。

$$
C_{0}=0.09134\left(J_{G}+J_{L}\right)+0.8273
$$

より広い流動条件に適用するためには、さらに流動様式等 の考慮が不可欠であるが，本実験の範囲内においては、式 (5)，(6)を式(2)-(4)に代入することにより定常時における $M_{i}$ を妥当な精度で予測可能と考えられる。なお、管内上昇気 泡流では, 流速の増加に伴って気泡はより管中央部に存在 しやすくなることが実験, 解析的に示されている(3)(4).この 場合、 $C_{0}$ は管中央における気相の存在割合の増加に伴って より大きい值をとるはずであり、図 3 に示される結果は管 内における気相の分布を反映したものと解釈できる.

\section{4. 支配方程式と数值解法}

本相関式を用いて一次元二流体モデルに基づく気液二相 流の非定常解析を実施し、定常データに基べく相関式の過 渡状態に対する適用性を検討する. 等温・非加熱で相変化 はないため, 解析に使用する基礎式は気相と液相に対する 質量および運動量の保存式である。解析では，上記界面せ 几断力の他，構成式として壁面せん断力と仮想質量力を考 慮する。また，一压力二流体モデルの数学的不適切性の問 題を回避するため, 液相中における界面平均圧力と体積平 均圧力の差の影響を考慮する。状態方程式では，液相は非 圧縮，気相は理想気体と仮定する，以上の支配方程式を半 陰解法に基づいて差分化し， Newton 法により求解する. 圧 力補正方程式の行列解法には TDMA 法を用いる(5).

\section{5. 計算結果}

過渡気液二相流の解析の一例として， $J_{L}=1.02 \mathrm{~m} / \mathrm{s}$ で一定 とし、 $W_{G}$ を $0.605 \mathrm{~g} / \mathrm{s}$ から $1.17 \mathrm{~g} / \mathrm{s}$ までステップ状に変化さ せたときの計測值と解析值の比較を図 4 に示す. 解析では, 気液の入口流量を入力とし，このときの圧力 $P$ および差圧 $\Delta P$ の変化を実験值と比較した。本図より, 過渡時において 解析值と実験値の差異が特に顕著となる傾向は見られず, 過渡の前後の定常状態と同様に過渡時においても妥当な予 測が行われていることが確認できる.

\section{6. 結言}

鉛直円管内における定常および過渡気液二相流の举動を 実験・解析的に調べた。今後より広範な条件での検討が不 可欠であるが，本実験の範囲内において得られた主な結果 を以下に要約する。

（1）圧力および差圧の観点では，定常状態において妥当な 予測を与える構成式を使用することにより，過渡状態 でも同等精度の予測が期待できる。

（2）分布定数は全体積流束とともに増加寸る傾向となった これは, 流路内のボイド分布を反映したものと推察さ れる。

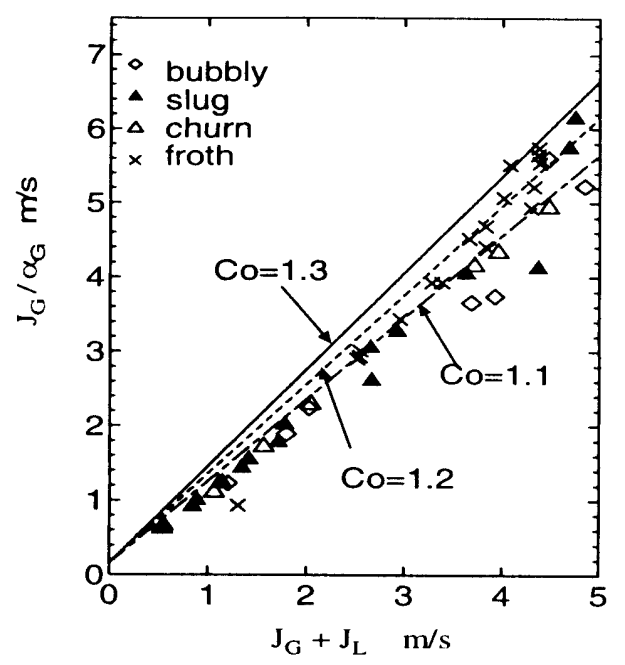

Fig. 2 Relation between $J_{G}+J_{L}$ and $J_{G} / \alpha_{G}$

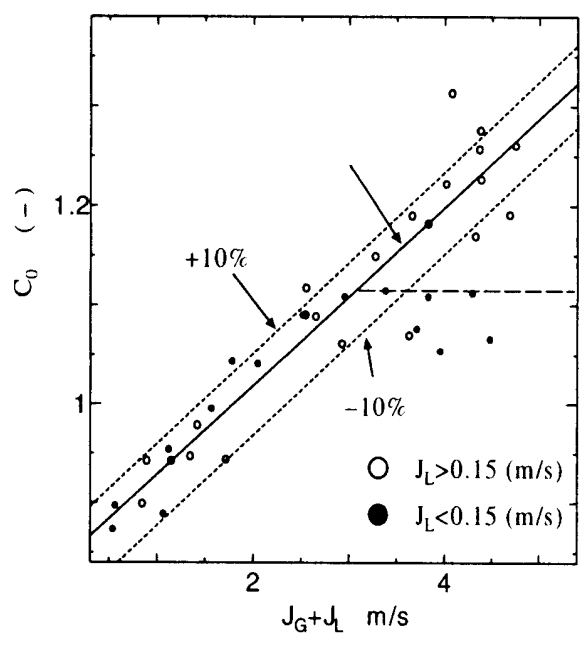

Fig. 3 Relation between $J_{G}+J_{L}$ and $C_{0}$
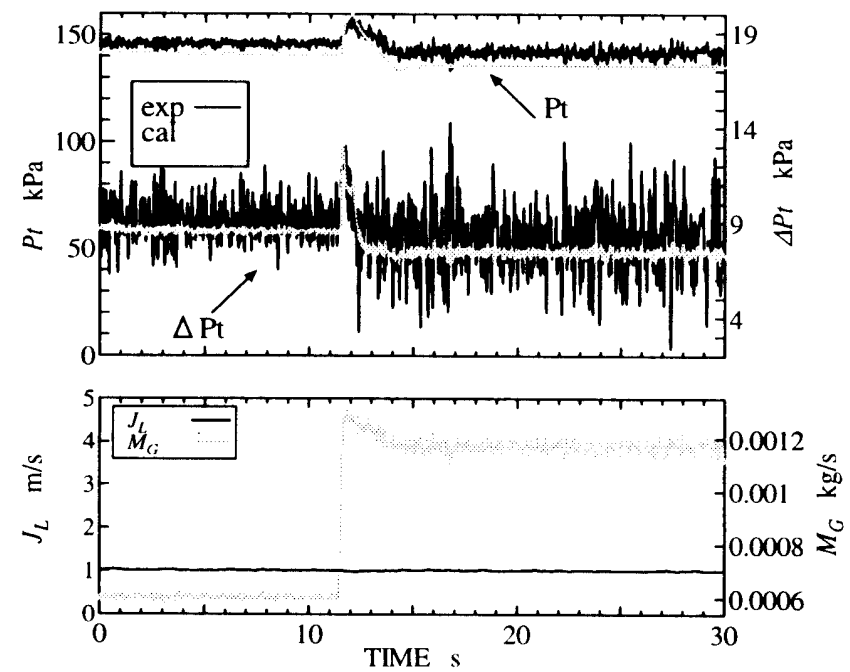

Fig. 4 Comparison of numerical solutions with experimental data in transient two-phase flow

参考文献 : (1) D. D. Taylor et al., NUREG/CR-3633, EGG-2294 (1984). (2) 植田辰洋, 気液二相流, 養賢堂 (1981). (3) A. Serizawa, I. Kataoka, Transient phenomena in multiphase flow (N. H. Afgan, Ed.), Hemisphere, 179-224 (1988). (4) T. Okawa, et al., Nucl. Eng. Des., 213, 183-197 (2002). (5) T. Okawa, et al., Int. J. Heat Mass Transfer, 45, 87-98 (2002). 